\title{
Emerging Trends and New Developments on Urban Resilience: A Bibliometric Perspective
}

\author{
Bo Pu1*, Yanjun Qiu' ${ }^{2}$ \\ ${ }^{1}$ School of Economics and Management, Southwest Jiaotong University, Chengdu, China \\ ${ }^{2}$ School of Civil and Engineering, Southwest Jiaotong University, Chengdu, China \\ Email: *ppuubo@hotmail.com
}

Received 18 February 2016; accepted 13 March 2016; published 16 March 2016

Copyright (C) 2016 by authors and Scientific Research Publishing Inc.

This work is licensed under the Creative Commons Attribution International License (CC BY). http://creativecommons.org/licenses/by/4.0/

(c) (i) Open Access

\begin{abstract}
Urban resilience is concerned by the scholars in the world, especially in light of new uncertainty challenges for cities such as natural disasters and man-made disasters. We performed a bibiometric analysis on urban resilience research based on the 1296 articles in the SCI, SCIE, SSCI and A\&HCI database from 1986 to 2015. Publication trends were discussed in HistCite to reveal the publication outputs, subject categories and publication pattern, most prolific authors and international productivity. The document co-citation analysis was made in CiteSpace III to explore the research basements and research trajectories, emerging trends and new developments. Growth of article output has emerged since 2003. Environmental studies and environmental sciences came out the most urban resilience articles. Ecology and Society was the most productive journal in this area. Barthel was the most prolific author. USA and UK were the most productive countries, and Arizona State University was the most high-productive institution, but the cooperation is lacking in the worldwide. Two streams were detected from the co-cited papers. "Governance", "climatechange" and "city" are research hotspots of urban resilience according to the strongest citation bursts of keywords, and Folke's paper published in 2006 has the strongest bursts. Future research will focus on ecosystem service, adaptive capacity and human-dominated ecosystem.
\end{abstract}

\section{Keywords}

Urban Resilience, Bibliometric Analysis, Research Fronts, Burst Analysis, CiteSpace

\section{Introduction}

Urbanization is a vital social development in the 21st century, as the global proportion of urban population has

"Corresponding author. 
increased from $28.3 \%$ to $50 \%$ in 2010 . While man is facing all sorts of emerging uncertainty challenges in social progress, such as natural disasters (e.g. earthquake, flood, drought, climate change, etc.) and man-made disasters (e.g. environmental pollution, war, terrorism, etc.). Urban resilience is a significant capacity to adjust to stress from hazards and to recover quickly from their impacts from catastrophe. Indeed, urban resilience can be seen in the context of risk and vulnerability assessments, institutional and social governance structures, resilience in (or of) different sectors (e.g. ecosystem, economy, etc.), and transformations of urban areas. In other words, to strengthen urban resilience is beneficial to reduce the influence of urban disaster.

To develop opportunities for the sustainable development of cities, researchers from multiple disciplines are studying the feedback, dynamics, and behavior of urban vulnerability and urban resilience in the face of urban crisis, such as the axioms and mean of urban resilience (Campanella, 2006; Surjan et al., 2011; Wilkinson, 2012; Childers et al., 2014), climate change and urban resilience (Grimm et al., 2008; Leichenko, 2011; Tyler \& Moench, 2012), spatial planning and urban resilience in the flood risk (Deppisch \& Schaerffer, 2011; Cruz et al., 2013; Lu, 2014), urban resilience and human-dominated ecosystems (Ernstson et al., 2010), urban infrastructure systems (Wilbanks et al., 2012; Ouyang \& Wang, 2015), urban resilience index (Attoh-Okine et al., 2009; Sellberg et al., 2015), urban social resilience (Cutter et al., 2010; Tate, 2012) and resilient cities (Godschalk, 2003; Pickett et al., 2004; Desouza \& Flanery, 2013; Vale, 2014). Further, topics on urban resilience and its related domain have become hot-debated focus (Beilin \& Wilkinson, 2015). It is necessary to describe the status qua on urban resilience studies for exploring the research basements and research fronts.

Some scholars have made some reviews on urban resilience or resilient cities (Lang, 2011; Müller, 2011; Chelleri, 2012; Jha et al., 2013; Cartalis, 2014), and bibliometric analysis could display the research performance and trajectories, emerging trends and new developments (Chen, 2006; Chen et al., 2014; Wang \& Liu, 2014; Kim \& Chen, 2015), but a review used bibliomeric analysis has been not much. However some researchers focused on resilience research (Xu et al., 2015; Meerow \& Newell, 2015) with bibliometric analysis. These studies could not get the map of the urban resilience research.

In this article, we will provide a comprehensive survey of the advance of urban resilience. More specifically, it aims to 1) present mainly publication outputs, subject categories and publication pattern, most-prolific authors and international productivity; 2) emerge the research basements and research trajectories by visualizing the citation network using CiteSpace III; 3) identify the research trends and new developments according to the keywords and cited references with strongest citation bursts.

\section{Data and Methods}

We established an analysis database of urban resilience from the Science Citation Index (SCI), Science Citation Index Expanded (SCIE), Social Science Citation Index (SSCI) and Arts and Humanities Citation Index (A\&HCI) supported by Web of Science. "Urban resilience” or "resilient city" or "resilient cities" were used as keywords to search from 1st January, 1986 to 5th August, 2015. Then we removed duplicate articles and got 1296 related articles.

Many available tools are used by bibliometric research, such as HistCite, CiteSpace, VOSviewer and Sci ${ }^{2}$ etc. HistCite is a flexible tool to provide research perspectives and information in our analysis database (Garfield, 2009) through GCS, LCS, LCR, LCS/t and GCS/t indicators, such as to analyze the classical literatures, to look for the productivity authors and institutions. Meanwhile, CiteSpace is popular to study the knowledge domain in a scientific field (Chen et al., 2014), can be used to analyze the knowledge basement and development track, to detect emerging trends and new developments.

\section{Empirical Results}

\subsection{Publication Outputs}

There has become a rapid increase on urban resilience work since 2003, as showed in Figure 1. According to the curve of publication number on urban resilience research, two stages can be notified. Before 2003: The articles number kept a low level. In this period, many workers paid great attention to the high-risk and resilient children, psychosocial resilience, urban children with stress resilient and stress affect outcomes, talked about that how to improve the human development in the city. After 2003: With the climate change and disasters increasing in the world, how to promote the orderly development of the city had attracted the attention of scholars. 
Pursuers of diverse disciplines to conduct researches on the resilient city and urban resilience from different angles. And the publication number grew from 12 in 2003 to 215 in 2014 steeply.

Regarding publishing language, eight languages were discovered among 1296 articles. 1275, or $98.4 \%$, of the articles were submitted in English. A few articles were published in Spanish (8), French (5), Portuguese (3), Slovenian (2), German (1), Polish (1) and Russian (1).

\subsection{Subject Categories and Publication Pattern}

Several ISI-defined subject categories were included, such as environmental studies, environmental sciences, urban studies, ecology, geography etc. We presented the uppermost 10 subject categories in Table 1 . The most common categories were environmental studies (260; 20.06\%), environmental sciences (203; 15.66\%), urban studies (176; 13.58\%), ecology $(141 ; 10.88)$. Meanwhile, we find out the urban resilience research has the nature of multidisciplinary, involves the environmental science, ecology, geography, psychology and social work etc.

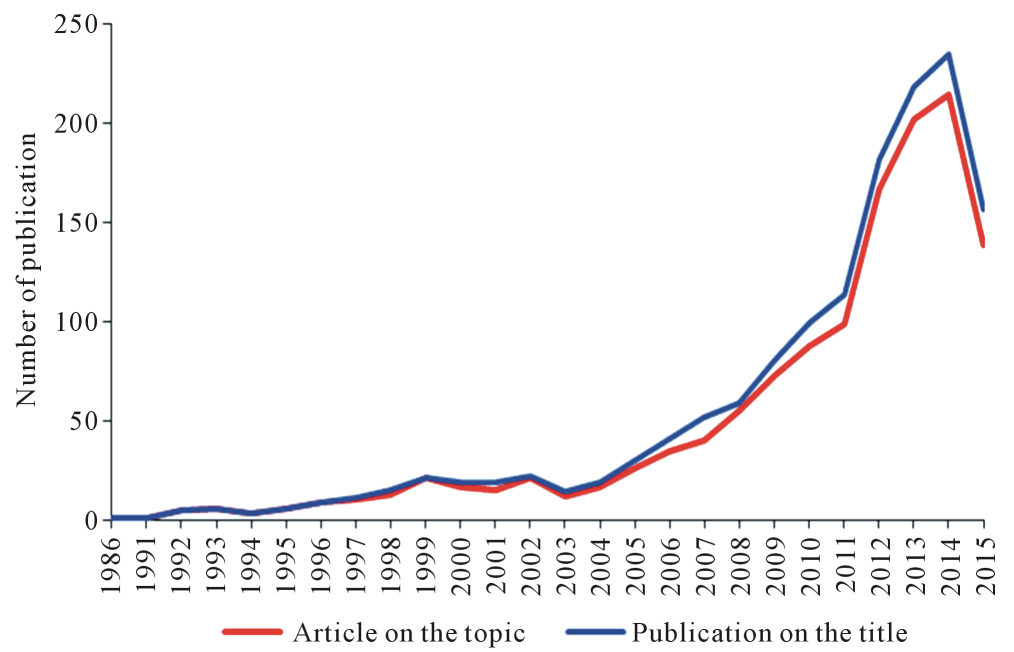

Figure 1. Growth of urban resilience study publications from 1986 to 2015.

Table 1. Distribution of the subject categories: the top 10 .

\begin{tabular}{ccc}
\hline Web of science subject category & TA & $\%$ \\
Environmental studies & 260 & 20.06 \\
Environmental sciences & 203 & 15.66 \\
Urban studies & 176 & 13.58 \\
Ecology & 141 & 10.88 \\
Geography & 128 & 9.88 \\
Public environmental occupational health & 109 & 8.41 \\
Water resources & 101 & 7.79 \\
Geosciences multidisciplinary & 69 & 5.32 \\
Psychology developmental & 69 & 5.32 \\
Planning development & 65 & 5.02 \\
\hline
\end{tabular}

TA, the number of articles on one subject category. 
These 1296 urban resilience articles were issued in 604 ISI-indexed journals. Maximum 18 active journals (2.98\% of the 604 journals) published 741 papers (21.84\%) out of a total of 1296 articles, while 388 journals (64.24\%) published only one paper. Table 2 showed the 18 most common journals on urban resilience research, along with the number of articles, the number of the LSC, LSC/t, GCS, GCS/t and LCR received. The main publication journal for urban resilience research included Ecology and Society, Environment and Urbanization, Landscape and Urban Planning, Sustainability, Urban Studies and Cities. In Ecology and Society, 34 articles, or 2.62\% out of the 1296 journals articles, were published, and received 543 GCS, 77.76 GCS/t and 22 LCR. Environment and Urbanization ranked second in terms of published numbers, with 28 articles, 43 LCS, 11.91 LCS/t, 218 GCS, 39.14 GCS/t and 20 LCR.

\subsection{Most-Prolific Authors and International Productivity}

3624 authors concentrated on the urban resilience and published related articles. However, only 67 scholars produced more than 4 papers, accounting for $1.85 \%$ of the total scholars, 3267 authors only had one article. Table 3 lists the 18 most productive authors, each with more than 5 published articles on related study. The most prolific author, Stephan Barthel and Rajib Shaw, had published 10 papers. Stephan Barthel work at Stockholm University in Sweden, with 47 LCS and 245 GCS. Rajib Shaw service for Kyoto University in Japan, with 4 LCS and 18 GCS. Other prolific authors included Kylie Bail, Emory L. Cowen, Peter A. Wyman, and so on. It is useful to mention that all the 18 most prolific scholars in Table 3, who come from developed countries.

\begin{tabular}{|c|c|c|c|c|c|c|c|c|}
\hline$\#$ & Journal name & TA & TA\% & LCS & $\mathrm{LCS} / \mathrm{t}$ & GCS & $\mathrm{GCS} / \mathrm{t}$ & LCR \\
\hline 1 & Ecology and Society & 34 & 2.62 & 0 & 0 & 543 & 77.76 & 22 \\
\hline 2 & Environment and Urbanization & 28 & 2.16 & 43 & 11.91 & 218 & 39.14 & 20 \\
\hline 3 & Landscape and Urban Planning & 25 & 1.93 & 60 & 10.10 & 300 & 54.46 & 33 \\
\hline 4 & Sustainability & 19 & 1.47 & 0 & 0 & 26 & 8.33 & 18 \\
\hline 5 & Urban Studies & 18 & 1.39 & 12 & 5.10 & 147 & 30.44 & 20 \\
\hline 6 & Cities & 17 & 1.31 & 12 & 4.75 & 62 & 22.95 & 33 \\
\hline 7 & Global Environmental Change-Human and Policy Dimensions & 15 & 1.16 & 38 & 8.08 & 192 & 44.21 & 20 \\
\hline 8 & Natural Hazards & 14 & 1.08 & 9 & 1.86 & 92 & 17.45 & 1 \\
\hline 9 & Natural Hazards and Earth System Sciences & 14 & 1.08 & 8 & 2.33 & 39 & 8.88 & 14 \\
\hline 10 & Building Research And Information & 13 & 1.00 & 5 & 1.72 & 47 & 11.21 & 11 \\
\hline 11 & Habitat International & 12 & 0.93 & 0 & 0 & 34 & 6.55 & 13 \\
\hline 12 & Water Science and Technology & 12 & 0.93 & 8 & 1.67 & 77 & 11.23 & 3 \\
\hline 13 & PLoS ONE & 11 & 0.85 & 0 & 0 & 45 & 16.00 & 1 \\
\hline 14 & Urban Education & 11 & 0.85 & 5 & 0.79 & 149 & 15.70 & 6 \\
\hline 15 & American Journal of Community Psychology & 10 & 0.77 & 33 & 2.51 & 251 & 23.15 & 15 \\
\hline 16 & Development and Psychopathology & 10 & 0.77 & 44 & 2.31 & 780 & 52.23 & 3 \\
\hline 17 & Environmental Hazards-Human and Policy Dimensions & 10 & 0.77 & 4 & 0.62 & 34 & 6.04 & 7 \\
\hline 18 & Urban Ecosystems & 10 & 0.77 & 2 & 0.67 & 36 & 10.60 & 2 \\
\hline
\end{tabular}

TA, total number of articles; TA\%, the percentage in the 3085 articles; LCS, local citation scores; LCS/t, local citation scores per year; GCS, global citation scores; GCS/t, global citation scores per year; LCR, local citied references. 
Table 3. The 18 most-productive authors.

\begin{tabular}{|c|c|c|c|c|c|c|c|c|}
\hline$\#$ & Author name & Full name & TA & LCS & $\mathrm{LCS} / \mathrm{t}$ & GCS & $\mathrm{GCS} / \mathrm{t}$ & Institute \\
\hline 1 & Barthel S & Stephan Barthel & 10 & 47 & 11.67 & 245 & 48.70 & Stockholm University \\
\hline 2 & Shaw $\mathrm{R}$ & Rajib Shaw & 10 & 4 & 0.79 & 18 & 4.36 & Kyoto University \\
\hline 3 & Bail K & Kylie Bail & 9 & 8 & 1.83 & 69 & 15.75 & Deakin University \\
\hline 4 & Cowen EL & Emory L. Cowen & 9 & 70 & 3.28 & 342 & 16.02 & University of Rochester \\
\hline 5 & Wyman PA & Peter A. Wyman & 9 & 70 & 3.28 & 342 & 16.02 & University of Rochester \\
\hline 6 & Colding J & Johan Colding & 8 & 39 & 7.67 & 218 & 32.53 & Stockholm University \\
\hline 7 & Elmqvist $\mathrm{T}$ & Thomas Elmqvist & 8 & 33 & 6.00 & 168 & 23.57 & Stockholm University \\
\hline 8 & Work WC & William C. Work & 8 & 68 & 3.15 & 336 & 15.62 & University of Rochester \\
\hline 9 & Brown RR & Rebekah R. Brown & 7 & 7 & 2.14 & 36 & 10.10 & Monash University \\
\hline 10 & Ernstson $\mathrm{H}$ & Henrik Ernstson & 7 & 33 & 6.83 & 183 & 34.38 & Stockholm University \\
\hline 11 & Masten AS & Ann S. Mastern & 7 & 18 & 1.21 & 458 & 36.64 & University of Minnesota Twin Cities \\
\hline 12 & Bradley B & Bekh Bradley & 6 & 2 & 0.40 & 37 & 7.97 & Emory University School of Medicine \\
\hline 13 & Broto VC & Vanesa Castan Broto & 6 & 5 & 2.00 & 44 & 16.5 & University College London \\
\hline 14 & Crawford D & David Crawford & 6 & 7 & 1.58 & 59 & 12.58 & Deakin University \\
\hline 15 & Pickett STA & Steward T.A. Pickett & 6 & 36 & 4.58 & 131 & 20.00 & Cary Institution of Ecosystem Studies \\
\hline 16 & Ressler KJ & Kerry J. Ressler & 6 & 3 & 0.54 & 63 & 10.82 & Emory University School of Medicine \\
\hline 17 & Wallace R & Rodrick Wallace & 6 & 9 & 0.68 & 51 & 4.41 & New York State Psychiatric Institution \\
\hline 18 & Zevenbergen $\mathrm{C}$ & Chris Zevenbergen & 6 & 11 & 1.86 & 47 & 8.13 & UNESCO-IHE \\
\hline
\end{tabular}

TA, total number of articles; LCS, local citation score; LCS/t, local citation scores per year; GCS, global citation score; GCS/t, global citation scores per year.

The 1296 urban resilience research articles were scattered geographic distribution in the world, and gathered mainly in the developed country. Five countries or regions contribute to the urban resilience research articles more than 50 papers, most of the countries or territories published less than 10 articles. United State was the most industrious country with 510 articles, and got the largest LCS (452) and GCS (8391), and had the largest average citation rate of LCS (0.89) and GCS (16.45). UK was the succeeding productive country with 203 articles, and received the second LCS (134) and GCS (1987). Australia was the third productive country (125), followed Canada (80) and Netherlands (52). Other prolific countries included Sweden (46), Germany (43), China (39), South Africa (39), and so on. More interestingly, the result confirmed that most of developed countries with post-urbanization paid attention to the urban resilience specially, and just a few developing countries with rapid urbanization has begun to emphasize the related research, such as China, South Africa, Brazil, India (see Table 4).

Institution distribution of urban resilience research was gathered, and mainly concentrated in several developed countries, such as USA, UK and Australia. Table 5 displayed the 21 most fruitful research institutions, each with more than 13 articles. Arizona State University was the most high-producing institution with 27 articles (2.08\% of the 1296 articles), followed closely by Stockholm University (24), University of Maryland (21), Yale University (21). About the urban resilience research, there are several sub-institutions in Arizona State 
University, such as school of sustainability, school of social work, school of geography science and urban planning et al. It is necessary to say that Stockholm Resilience Centre was established on 1st January 2007, to advances research on the governance of social-ecological systems with a special emphasis on resilience.

\subsection{Research Basement and Research Trajectories}

According to the Figure 2 and Table 6, two research streams have been formed. A big stream (A) as Figure 2 on the right, which paid more attention to urban resilience in the ecology perspective. It was started by Holling's (1973) paper called "resilience and stability of ecological systems" in Annual review of ecology and systematics. These studies focused on resilience theory (Gunderson \& Holling, 2002; Adger, 2006; Smit \& Wandel, 2006), the resilience of ecological system (Holling, 1973; Grimm et al., 2000), the resilience of social-ecological system (Adger, 2000; Folke et al., 2005; Folke, 2006), resilient city (Pelling, 2003; Pickett et al., 2004; Grimm et al., 2008), disaster and resilience (Carpenter et al., 2001; Berkes et al., 2003; Wisner et al., 2004). Another stream (B) concentrated on the psychology and resilience (Rutter, 1987; Masten et al., 1990; Luthar et al., 2000), high-risk children and resilience (Werner \& Smit, 1982; Werner \& Smith, 1992).

Table 4. Top 20 productive country of urban resilience research.

\begin{tabular}{|c|c|c|c|c|c|c|c|}
\hline$\#$ & Country & TA & TA\% & LCS & LCS/TA & GCS & GCS/TA \\
\hline 1 & USA & 510 & 39.35 & 452 & 0.89 & 8391 & 16.45 \\
\hline 2 & UK & 203 & 15.66 & 134 & 0.66 & 1987 & 9.79 \\
\hline 3 & Australia & 125 & 9.65 & 47 & 0.38 & 773 & 6.18 \\
\hline 4 & Canada & 80 & 6.17 & 11 & 0.14 & 535 & 6.69 \\
\hline 5 & Netherlands & 52 & 4.01 & 34 & 0.65 & 288 & 5.54 \\
\hline 6 & Sweden & 46 & 3.55 & 90 & 1.96 & 573 & 12.46 \\
\hline 7 & Germany & 43 & 3.32 & 16 & 0.37 & 219 & 5.09 \\
\hline 8 & China & 39 & 3.01 & 19 & 0.49 & 303 & 7.77 \\
\hline 9 & South Africa & 39 & 3.01 & 47 & 1.21 & 261 & 6.69 \\
\hline 10 & Italy & 38 & 2.93 & 11 & 0.29 & 233 & 6.13 \\
\hline 11 & Spain & 36 & 2.78 & 6 & 0.17 & 272 & 7.56 \\
\hline 12 & France & 31 & 2.39 & 26 & 0.84 & 195 & 6.29 \\
\hline 13 & Japan & 23 & 1.77 & 5 & 0.22 & 38 & 1.65 \\
\hline 14 & Brazil & 19 & 1.47 & 0 & 0.00 & 171 & 9.00 \\
\hline 15 & New Zealand & 19 & 1.47 & 9 & 0.47 & 296 & 15.58 \\
\hline 16 & Belgium & 16 & 1.23 & 4 & 0.25 & 86 & 5.38 \\
\hline 17 & India & 16 & 1.23 & 4 & 0.25 & 68 & 4.25 \\
\hline 18 & Switzerland & 16 & 1.23 & 4 & 0.25 & 173 & 10.81 \\
\hline 19 & Israel & 14 & 1.08 & 5 & 0.36 & 129 & 9.21 \\
\hline 20 & Portugal & 11 & 0.85 & 2 & 0.18 & 44 & 4.00 \\
\hline
\end{tabular}

TA, total number of articles; TA\%, the percentage of the 3085 article; LCS, local citation score; GCS, global citation score. 
Table 5. Top 21 productive research institutions of urban resilience research.

\begin{tabular}{|c|c|c|c|c|c|}
\hline \# & Institution & TA & TA\% & LCS & GCS \\
\hline 1 & Arizona State University & 27 & 2.08 & 47 & 727 \\
\hline 2 & Stockholm University & 24 & 1.85 & 83 & 501 \\
\hline 3 & University of Maryland & 21 & 1.62 & 9 & 484 \\
\hline 4 & Yale University & 21 & 1.62 & 27 & 443 \\
\hline 5 & University College London & 20 & 1.54 & 20 & 180 \\
\hline 6 & Columbia University & 19 & 1.47 & 30 & 439 \\
\hline 7 & Monash University & 19 & 1.47 & 16 & 110 \\
\hline 8 & University Melbourne & 18 & 1.39 & 4 & 122 \\
\hline 9 & Harvard University & 16 & 1.23 & 4 & 176 \\
\hline 10 & US Forest Service & 16 & 1.23 & 7 & 130 \\
\hline 11 & University Birmingham & 15 & 1.16 & 16 & 85 \\
\hline 12 & University N Carolina & 15 & 1.16 & 22 & 351 \\
\hline 13 & University Wisconsin & 15 & 1.16 & 10 & 339 \\
\hline 14 & Emory University & 14 & 1.08 & 10 & 255 \\
\hline 15 & University Colorado & 14 & 1.08 & 13 & 675 \\
\hline 16 & University Manchester & 14 & 1.08 & 30 & 154 \\
\hline 17 & Deakin University & 13 & 1.00 & 8 & 86 \\
\hline 18 & Kings College London & 13 & 1.00 & 5 & 187 \\
\hline 19 & Kyoto University & 13 & 1.00 & 5 & 28 \\
\hline 20 & University British Columbia & 13 & 1.00 & 3 & 127 \\
\hline 21 & University California Berkeley & 13 & 1.00 & 11 & 198 \\
\hline
\end{tabular}

TA, total number of articles; TA\%, the percentage in the 3085 article; LCS, local citation score; GCS, global citation score.

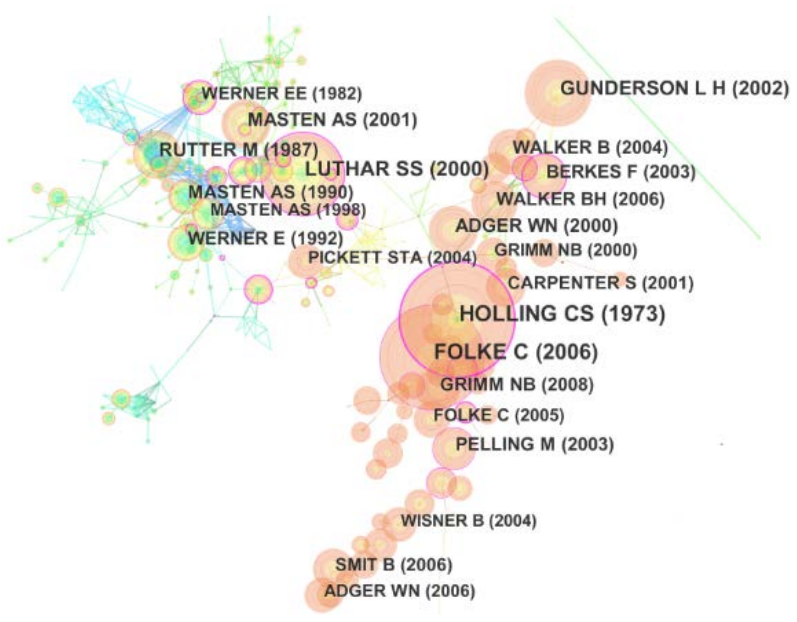

Figure 2. Co-cited of paper on the urban resilience. 
Table 6. Research basements and research streams.

\begin{tabular}{|c|c|c|c|}
\hline \# & Article information & Frequence & Stream \\
\hline 1 & Holling, 1973, Annual Rev Ecol Syst, V4, P1 & 97 & A \\
\hline 2 & Folke, 2006, GLOBAL ENVIRON CHANG, V16, P253 & 85 & A \\
\hline 3 & Luthar et al., 2000, CHILD DEV, V71, P543 & 69 & B \\
\hline 4 & Gunderson \& Holling, 2002, PANARCHY UNDERSTANDI & 58 & A \\
\hline 5 & Rutter, 1987, AM J ORTHOPSYCHIAT, V57, P316 & 48 & B \\
\hline 6 & Walker et al., 2004, ECOL SOC, V9 & 46 & A \\
\hline 7 & Masten, 2001, AM PSYCHOL, V56, P227 & 44 & B \\
\hline 8 & Adger, 2000, PROG HUM GEOG, V24, P347 & 42 & A \\
\hline 9 & Walker et al., 2006, RESILIENCE THINKING & 40 & A \\
\hline 10 & Berkes et al., 2003, NAVIGATING SOCIAL EC & 38 & A \\
\hline 11 & Grimm et al., 2008, SCIENCE, V319, P756 & 37 & A \\
\hline 12 & Pelling, 2003, VULNERABILITY CITIES & 37 & A \\
\hline 13 & Werner \& Smith, 1992, OVERCOMING ODDS HIGH & 37 & B \\
\hline 14 & Masten et al., 1990, DEV PSYCHOPATHOL, V2, P425 & 36 & B \\
\hline 15 & Smit \& Wandel, 2006, GLOBAL ENVIRON CHANG, V16, P282 & 35 & A \\
\hline 16 & Carpenter et al., 2001, ECOSYSTEMS, V4, P765 & 34 & A \\
\hline 17 & Werner \& Smit, 1982, VULNERABLE INVINCIBL & 33 & B \\
\hline 18 & Folke et al., 2005, ANNU REV ENV RESOUR, V30, P441 & 32 & A \\
\hline 19 & Adger, 2006, GLOBAL ENVIRON CHANG, V16, P268 & 31 & A \\
\hline 20 & Grimm et al., 2000, BIOSCIENCE, V50, P571 & 31 & A \\
\hline 21 & Masten \& Coatsworth, 1998, AM PSYCHOL, V53, P205 & 31 & B \\
\hline 22 & Pickett et al., 2004, LANDSCAPE URBAN PLAN, V69, P369 & 31 & A \\
\hline 23 & Wisner et al., 2004, RISK NATURAL HAZARDS, V2nd & 30 & A \\
\hline
\end{tabular}

\section{Emerging Trends and New Developments}

\subsection{Temporal Evolution of Keywords}

Keywords are vital components of the article, and it will show the research focus to analyze the keywords frequency and keywords centricity. As Table 7 showed, in the past study, according to frequency the top 10 keywords were resilience, vulnerability, management, cities, risk, adaptation, systems, children, climate change and urban. However, the top six keywords were biodiversity, adolescents, youth, resilience, ecosystem services and vulnerability, looking from the keywords centrality. United-states as a keyword, had been mentioned 43 times with 0.01 centrality. There are limited reasons, firstly many scholars are interested in urban resilience in USA, and secondly USA is the representative of the developed country.

Similarly, keywords will identify research fronts to explore the burstness of keywords. Some fast growing topics will be detected by analyzing busts. As Table 8 showed, competence has the strongest bursts among 
Table 7. Top 24 keywords frequence and centrality.

\begin{tabular}{|c|c|c|c|c|c|c|c|c|c|}
\hline \# & Keywords & Frequence & Centrality & Year & \# & Keywords & Frequence & Centrality & Year \\
\hline 1 & Resilience & 484 & 0.15 & 1993 & 13 & Health & 62 & 0.01 & 2002 \\
\hline 2 & Climate-change & 155 & 0.07 & 2007 & 14 & Biodiversity & 56 & 0.42 & 2004 \\
\hline 3 & Vulnerability & 128 & 0.09 & 1995 & 15 & Adolescents & 55 & 0.30 & 1993 \\
\hline 4 & Management & 116 & 0.08 & 2004 & 16 & City & 53 & 0.01 & 2004 \\
\hline 5 & Cities & 106 & 0.05 & 2004 & 17 & Ecosystem services & 52 & 0.13 & 2005 \\
\hline 6 & Risk & 92 & 0.03 & 1996 & 18 & Governance & 47 & 0.01 & 2013 \\
\hline 7 & Adaptation & 90 & 0.07 & 2010 & 19 & Youth & 46 & 0.19 & 1994 \\
\hline 8 & Systems & 84 & 0.01 & 2008 & 20 & Framework & 46 & 0.01 & 2010 \\
\hline 9 & Children & 80 & 0.04 & 1993 & 21 & Stress & 43 & 0.08 & 1993 \\
\hline 10 & Urban & 71 & 0.01 & 2001 & 22 & United-states & 43 & 0.01 & 1993 \\
\hline 11 & Sustainability & 69 & 0.04 & 2004 & 23 & Impact & 42 & 0.01 & 2005 \\
\hline 12 & Social-ecological systems & 62 & 0.05 & 2010 & 24 & Urbanization & 42 & 0.01 & 2007 \\
\hline
\end{tabular}

Table 8. Top 20 keywords with strongest citation bursts.

\begin{tabular}{|c|c|c|c|c|c|}
\hline Keywords & Year & Strength & Begin & End & 1986-2015 \\
\hline Competence & 1986 & 12.0149 & 1986 & 2007 & \\
\hline Childhood & 1986 & 5.3831 & 1992 & 2008 & \\
\hline Family & 1986 & 5.4281 & 1993 & 2004 & \\
\hline Children & 1986 & 8.1744 & 1994 & 2005 & \\
\hline Youth & 1986 & 5.3045 & 1994 & 2006 & \\
\hline Adolescents & 1986 & 6.1366 & 1995 & 2003 & \\
\hline Behavior & 1986 & 6.4017 & 1996 & 2003 & \\
\hline Urban children & 1986 & 5.4304 & 1996 & 2004 & \\
\hline Prevention & 1986 & 4.5489 & 1996 & 2009 & \\
\hline Protective factors & 1986 & 4.4138 & 1996 & 2005 & \\
\hline Delinquency & 1986 & 4.1046 & 1996 & 2003 & \\
\hline Outcomes & 1986 & 3.5142 & 1996 & 2005 & \\
\hline Social support & 1986 & 3.7974 & 1998 & 2007 & \\
\hline Adjustment & 1986 & 11.0837 & 1999 & 2008 & \\
\hline Community violence & 1986 & 3.6593 & 2003 & 2007 & \\
\hline New York city & 1986 & 4.7616 & 2006 & 2008 & \\
\hline Posttraumatic-stress-disorder & 1986 & 3.8927 & 2006 & 2011 & \\
\hline Governance & 1986 & 6.9628 & 2013 & 2015 & \\
\hline Climate-change & 1986 & 5.7883 & 2013 & 2015 & \\
\hline City & 1986 & 4.1326 & 2013 & 2015 & \\
\hline
\end{tabular}


keywords, with 12.0149 burst strength and burst duration from 1986 to 2007. Adjustment was the second strongest citation burst (10.9996) in the period of 1999 and 2008, followed children (8.1744), government (6.9628) and behavior (6.4017). It meant nothing worth that three keywords ("governance”, "climate-change”, "city") are research focus in the future from the time.

\subsection{Burstness of the References}

Burst detection and visualization can be implemented to different types of nodes for finding out the research basement of future research. Table 9 displays the top 20 high citation bursts of articles about urban resilience. From the list, Folke (2006) has the strongest bursts among articles published in Global Environmental Change, with 14.1352 burst value and burst duration from 2013 to 2015. It is further curious to note that Luther et al. (2000) has the second strongest citation burst in the period of 2005 and 2011. However, some papers will be research basements for future research, such as Folke (2006), Cutter et al. (2008) and Barthel et al. (2010) in the field of environmental change, Walker et al. (2006) in the theory of resilience, Davoudi et al. (2012) in planning areas, Walker et al. (2004) and Folke et al. (2010) in the ecological society areas.

Table 9. Top 20 references with strongest citation bursts.

\begin{tabular}{|c|c|c|c|c|c|}
\hline References & Year & Strength & Begin & End & $1986-2015$ \\
\hline Werner, 1989, Am J Orthopsychiat, V59, P72 & 1989 & 5.3538 & 1986 & 2001 & \\
\hline Rutter, 1987, Am J Orthopsychiat, V57, P316 & 1987 & 7.1107 & 1993 & 2000 & \\
\hline Werner \& Smith, 1992, Overcoming Odds High, V, P & 1992 & 6.6177 & 1993 & 2008 & \\
\hline Masten et al., 1990, Dev Psychopathol, V2, P425 & 1990 & 6.3382 & 1993 & 2004 & \\
\hline Wyman et al., 1991, Am J Commun Psychol, V19, P405 & 1991 & 5.5104 & 1993 & 2002 & -_C_-_ \\
\hline Wyman et al., 1992, J Am Acad Child Psy, V31, P904 & 1992 & 5.4153 & 1993 & 2001 & \\
\hline Masten \& Coatsworth, 1998, Am Psychol, V53, P205 & 1998 & 8.5880 & 1999 & 2008 & 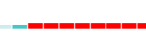 \\
\hline Mcloyd, 1998, Am Psychol, V53, P185 & 1998 & 5.4108 & 2000 & 2009 & 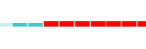 \\
\hline Luthar et al., 2000, Child Dev, V71, P543 & 2000 & 8.7105 & 2005 & 2011 & \\
\hline Godschalk, 2003, Nat Hazards Rev, V4, P136 & 2003 & 6.9447 & 2012 & 2015 & \\
\hline Cutter et al., 2003, Soc Sci Quart, V84, P242 & 2003 & 6.5584 & 2012 & 2013 & \\
\hline Cutter et al., 2008, Global Environ Chang, V18, P598 & 2008 & 5.9203 & 2012 & 2015 & \\
\hline Wisner et al., 2004, Risk Natural Hazards, V2nd, P & 2004 & 5.4874 & 2012 & 2015 & \\
\hline Folke, 2006, Global Environ Chang, V16, P253 & 2006 & 14.1352 & 2013 & 2015 & \\
\hline Walker et al., 2006, Resilience Thinking, V, P & 2006 & 7.0720 & 2013 & 2015 & \\
\hline Davoudi et al., 2012, Planning Theory Prac, V13, P299 & 2012 & 6.9824 & 2013 & 2015 & \\
\hline Ernstson et al., 2010, Ambio, V39, P531 & 2010 & 6.0370 & 2013 & 2015 & \\
\hline Walker et al., 2004, Ecol Soc, V9, P & 2004 & 5.9948 & 2013 & 2015 & \\
\hline Folke et al., 2010, Ecol Soc, V15, P & 2010 & 5.7072 & 2013 & 2015 & \\
\hline Barthel, 2010, Global Environ Chang, V20, P255 & 2010 & 5.3367 & 2013 & 2015 & \\
\hline
\end{tabular}




\subsection{Clusters of Co-Cited References from 1986 to 2015}

To identify further development clearly, we showed a timeline visualization based on the dataset which we gathered. Visualized clusters are defined based on citation instances made by the top 50 most-cited articles per three years from 1986 to 2015. Timeline visualizations can be revealed the newly emerged threads. Timeline visualization for $\mathrm{T}_{1986-2015}$ is showed in Figure 3, animatedly. The largest cluster is cluster \#0 on ecosystem services, and the largest circles with red rings depict the references to Holling (1973). Some recent developments since 2010 are presented in Figure 3 as the clusters' labels. New clusters include \#2 on adaptive capacity and \# 11 on human-dominated ecosystem.

A more detailed visualization was obtained to further investigate new developments about urban resilience as showed Table 10. The largest cluster \#0 ecosystem service has over 30 references as its members with an average year of publication of 1999. It was high silhouette value of 0.932 indicates a high homogeneity of the cluster.

The largest cluster was formed by more recently published articles, which was \#11 and labeled as humandominated ecosystem. This cluster had ten members and an average year of publication of 2007. And Table 11 showed seven articles in cluster \#11 with the strongest citation bursts. Folke is undoubtedly the major contributors of social-ecological system on urban resilience. Meanwhile, Folke's (2006) paper held the strongest citation bursts in this cluster. Table 12 showed three most-representative articles of cluster \#11. Ernstson et al.’s (2010) work had combined urban resilience and human-dominated ecosystem. This is a mainstream of the present study on urban resilience.

The other cluster included cluster \#2, which was labeled as disaster resilience indicator and adaptive capacity. Table 13 lists nine articles in cluster \#2 with the strongest citation bursts. Tilte terms include Resilience, vulnerability, hazards and adaptability. Cutter has been focused on the social vulnerability and social resilience, and published a large number of articles. Davoudi et al. (2012) has the strongest citation bursts in this cluster.

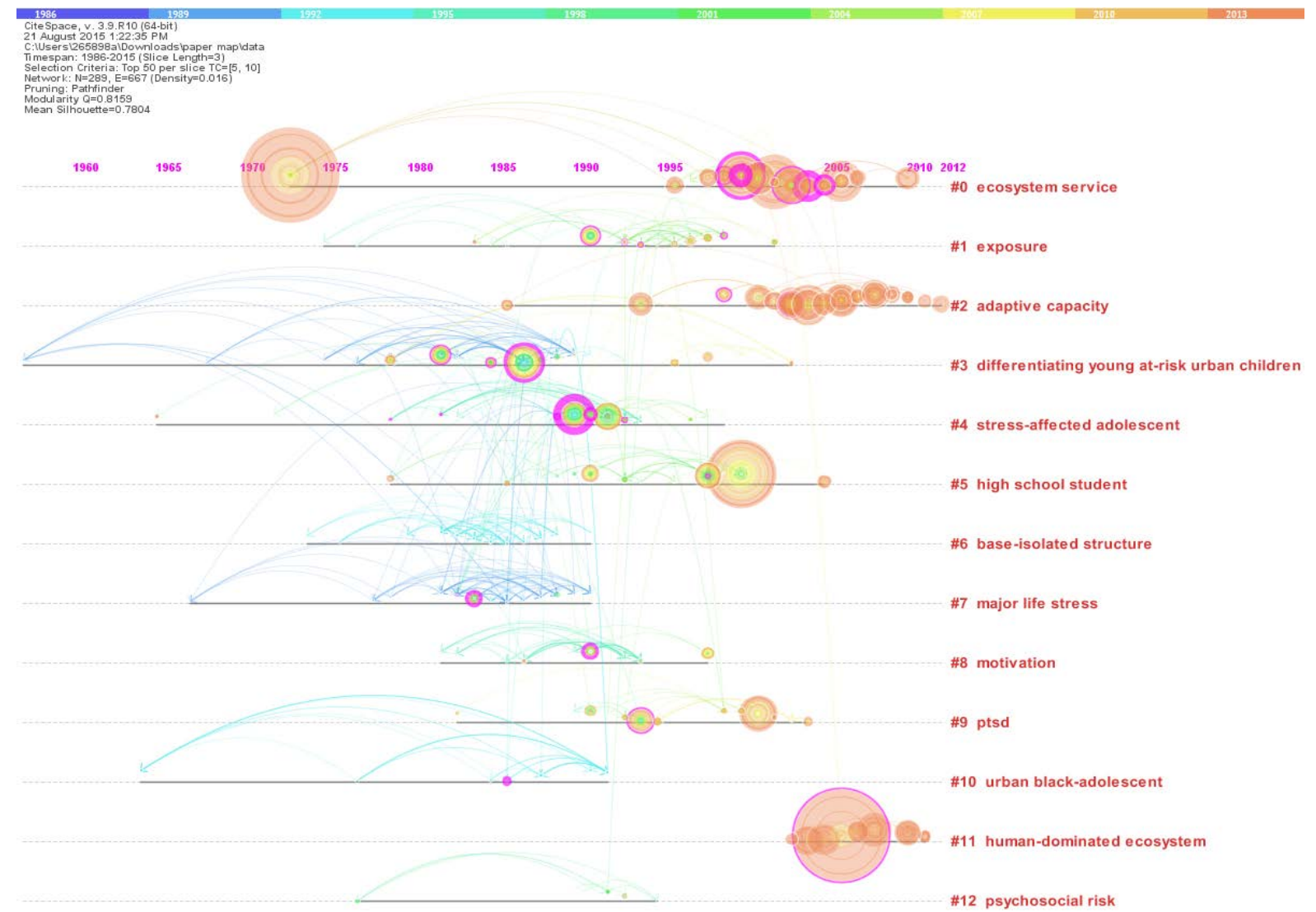

Figure 3. A timeline visualization for $T_{1986-2015}$ is shown. New developments since 2010 are included in the visualization, notably in association with clusters \#2 and \#11. 
Table 10. Largest clusters of co-cited references among the 43 clusters.

\begin{tabular}{|c|c|c|c|c|c|c|}
\hline Cluster ID & Size & Silhouette & Average year & Label by TF*IDF & $\begin{array}{l}\text { Label by } \\
\text { log-likelihood ratio }\end{array}$ & $\begin{array}{l}\text { Label by mutual } \\
\text { information }\end{array}$ \\
\hline 0 & 31 & 0.932 & 1999 & Ecosystem service & Management & India \\
\hline 1 & 30 & 0.842 & 1992 & Exposure & Community violence & $\begin{array}{l}\text { Homeless urban } \\
\text { adolescent mother }\end{array}$ \\
\hline 2 & 28 & 0.951 & 2004 & Adaptive capacity & $\begin{array}{c}\text { Disaster resilience } \\
\text { indicator }\end{array}$ & Year \\
\hline 3 & 27 & 0.816 & 1986 & $\begin{array}{l}\text { Differentiating young } \\
\text { at-risk urban children }\end{array}$ & $\begin{array}{l}\text { Differentiating young } \\
\text { at-risk urban children }\end{array}$ & Turnaround process \\
\hline 4 & 26 & 0.800 & 1989 & $\begin{array}{l}\text { Stress-affected } \\
\text { adolescent }\end{array}$ & $\begin{array}{l}\text { Stress-affected } \\
\text { adolescent }\end{array}$ & Year \\
\hline 5 & 26 & 0.854 & 1993 & High school student & High school student & Community \\
\hline 6 & 20 & 1.00 & 1983 & Base-isolated structure & Base-isolated structure & Earthquake \\
\hline 7 & 20 & 0.853 & 1984 & Major life stress & Major life stress & Promotion \\
\hline 8 & 20 & 0.947 & 1990 & Motivation & Motivation & Turnaround process \\
\hline 9 & 20 & 0.900 & 1996 & PTSD & Disaster & Community \\
\hline 10 & 12 & 0.978 & 1986 & Urban black-adolescent & Urban black-adolescent & School psychologist \\
\hline 11 & 10 & 0.977 & 2007 & $\begin{array}{c}\text { Human-dominated } \\
\text { ecosystem }\end{array}$ & $\begin{array}{c}\text { Human-dominated } \\
\text { ecosystem }\end{array}$ & Case study \\
\hline 12 & 8 & 0.991 & 1988 & Psychosocial risk & Protective factor & Moderator effect \\
\hline
\end{tabular}

Table 11. Articles with strongest citation busts in cluster \#11.

\begin{tabular}{|c|c|c|c|c|c|}
\hline Citation & Burst & Author & Year & Title & Source \\
\hline 85 & 14.14 & Folke & 2006 & $\begin{array}{l}\text { Resilience: The emergence of a perspective } \\
\text { for social-ecological systems analyses }\end{array}$ & GLOBAL ENVIRON CHANG \\
\hline 24 & 6.04 & Ernstson et al. & 2010 & $\begin{array}{c}\text { Scale-crossing brokers and network governance } \\
\text { of urban ecosystem services: the case of } \\
\text { stockholm }\end{array}$ & AMBIO \\
\hline 25 & 5.71 & Folke et al. & 2010 & $\begin{array}{l}\text { Resilience thinking: integrating resilience, } \\
\text { adaptability and transformability }\end{array}$ & ECOL SOC \\
\hline 14 & 4.44 & Evans & 2011 & $\begin{array}{l}\text { Resilience, ecology and adaptation in the } \\
\text { experimental city }\end{array}$ & T I BRIT GEOGR \\
\hline 31 & 4.43 & Pickett et al. & 2004 & $\begin{array}{l}\text { Resilient cities: meaning, models, and } \\
\text { metaphor for integrating the ecological, } \\
\text { socio-economic, and planning realms }\end{array}$ & LANDSCAPE URBAN PLAN \\
\hline 32 & 3.94 & Folke et al. & 2005 & $\begin{array}{l}\text { Adaptive governance of } \\
\text { social-ecological systems }\end{array}$ & ANNU REV ENV RESOUR \\
\hline 13 & 3.57 & Ahern & 2011 & $\begin{array}{l}\text { From fail-safe to safe-to-fail: Sustainability } \\
\text { and resilience in the new urban world }\end{array}$ & LANDSCAPE URBAN PLAN \\
\hline
\end{tabular}


Table 12. Articles that cite over $20 \%$ members of cluster \#11.

\begin{tabular}{cl}
\hline Coverage (\%) & \multicolumn{1}{c}{ Articles citing cluster \#11 } \\
\hline 50 & Ernstson, Henrik et al. (2010) urban transitions: on urban resilience and human-dominated ecosystems \\
40 & $\begin{array}{l}\text { Ernstson, Henrik et al. (2010) scale-crossing brokers and network governance of urban ecosystem services: the case of } \\
\text { stockholm }\end{array}$ \\
\hline 20 & Wilkinson, Cathy (2012) social-ecological resilience: insights and issues for planning theory \\
\hline
\end{tabular}

Table 13. Articles with strongest citation busts in cluster \#2.

\begin{tabular}{|c|c|c|c|c|c|}
\hline Citation & Burst & Author & Year & Title & Source \\
\hline 19 & 6.98 & Davoudi et al. & 2012 & Resilience: A Bridging Concept or a Dead End? & PLANNING THEORY PRAC \\
\hline 26 & 6.94 & Godschalk & 2003 & Urban hazard mitigation: creating resilient cities & NAT HAZARDS REV \\
\hline 26 & 6.56 & Cutter et al. & 2003 & Social vulnerability to environmental hazards & SOC SCI QUART \\
\hline 39 & 5.99 & Walker et al. & 2004 & $\begin{array}{l}\text { Resilience, adaptability and transformability } \\
\text { in social-ecological systems }\end{array}$ & ECOL SOC \\
\hline 24 & 5.92 & Cutter et al. & 2008 & $\begin{array}{l}\text { A place-based model for understanding } \\
\text { community resilience to natural disasters }\end{array}$ & $\begin{array}{l}\text { GLOBAL ENVIRON } \\
\text { CHANG }\end{array}$ \\
\hline 30 & 5.49 & Wisner et al. & 2004 & $\begin{array}{l}\text { At Risk: Natural hazards, people's } \\
\text { vulnerability and disasters }\end{array}$ & BOOK \\
\hline 28 & 4.93 & Norris et al. & 2008 & $\begin{array}{l}\text { Community resilience as a metaphor, theory, set } \\
\text { of capacities, and strategy for disaster readiness }\end{array}$ & AM J COMMUN PSYCHOL \\
\hline 21 & 4.52 & Folke et al. & 2002 & $\begin{array}{l}\text { Resilience and sustainable development: building } \\
\text { adaptive capacity in a world of transformations }\end{array}$ & AMBIO \\
\hline 18 & 4.52 & Newman et al. & 2009 & $\begin{array}{l}\text { Resilient cities: responding to peak oil } \\
\text { and climate change }\end{array}$ & BOOK \\
\hline
\end{tabular}

\section{Conclusions}

In this paper, we have provided bibliometric techniques on research trends in the urban resilience research, based on the 1296 articles, which were downloaded in the Web of Science during the period from 1986 to 2015. The paper presented publication outputs, subject categories and publication pattern, most prolific authors and international productivity, research basements and research trajectories, emerging trends and new developments. Works show that the article number on urban resilience has increased since 2003. Environmental studies and environmental sciences came out the most related papers. Meanwhile, Ecology and Society and Environment and Urbanizations were the most-prolific journal; Barthel was the most-prolific author. In addition, most research of urban resilience was dominated by USA and UK, and Arizona State University was the most highproductive institution.

Two streams were identified. One stream paid attention to social-ecological system of urban, others focused on psychology and resilience. According to the bursts of the node, these keywords were research hotpots, such as "government", "climate-change" and "city"; the articles were the research basement of future research, such as Cutter et al. (2008), Folke (2006), Davoudi et al. (2012) and Walker et al. (2006). Future research will focus on three areas mainly, such as ecosystem service, adaptive capacity and human-dominated ecosystem. With the development of global city, more topics will be concerned, such as the metrics of urban resilience, the relationship between leisure city and resilient city, urban vulnerability and urban resilience.

\section{Acknowledgements}

The authors are grateful to Southwest Jiaotong University in China, for his valuable inputs. This research is 
supported by funding from Ministry of Education of Humanities and Social Science Project of China (No. 13YJA880058) and China Scholarship Council (CSC) (No. 201507000007).

\section{References}

Adger, W. N. (2000). Social and Ecological Resilience: Are They Related? Progress in Human Geography, 24, 347-364. http://dx.doi.org/10.1191/030913200701540465

Adger, W. N. (2006). Vulnerability. Global Environmental Change, 16, 268-281. http://dx.doi.org/10.1016/j.gloenvcha.2006.02.006

Ahern, J. (2011). From Fail-Safe to Safe-to-Fail: Sustainability and Resilience in the New Urban World. Landscape and Urban Planning, 100, 341-343. http://dx.doi.org/10.1016/j.landurbplan.2011.02.021

Attoh-Okine, N. O., Cooper, A. T., \& Mensah, S. (2009). Formulation of Resilience Index of Urban Infrastructure Using Belief Functions. Systems Journal, IEEE, 3, 147-153. http://dx.doi.org/10.1109/JSYST.2009.2019148

Barthel, S., Folke, C., \& Colding, J. (2010). Social-Ecological Memory in Urban Gardens-Retaining the Capacity for Management of Ecosystem Services. Global Environmental Change, 20, 255-265. http://dx.doi.org/10.1016/j.gloenvcha.2010.01.001

Beilin, R., \& Wilkinson, C. (2015). Introduction: Governing for Urban Resilience. Urban Studies, 52, 1205-1217. http://dx.doi.org/10.1177/0042098015574955

Berkes, F., Colding, J., \& Folke, C. (2003). Navigating Nature’s Dynamics: Building Resilience for Complexity and Change. New York: Cambridge.

Campanella, T. J. (2006). Urban Resilience and the Recovery of New Orleans. Journal of the American Planning Association, 72, 141-146. http://dx.doi.org/10.1080/01944360608976734

Carpenter, S., Walker, B., Anderies, J. M., \& Abel, N. (2001). From Metaphor to Measurement: Resilience of What to What? Ecosystems, 4, 765-781. http://dx.doi.org/10.1007/s10021-001-0045-9

Cartalis, C. (2014). Toward Resilient Cities-A Review of Definitions, Challenges and Prospects. Advances in Building Energy Research, 8, 259-266. http://dx.doi.org/10.1080/17512549.2014.890533

Chelleri, L. (2012). From the "Resilient City" to Urban Resilience. A Review Essay on Understanding and Integrating the Resilience Perspective for Urban Systems. Documents d'Anàlisi Geogràfica, 58, 287-306.

Chen, C. (2006). CiteSpace II: Detecting and Visualizing Emerging Trends and Transient Patterns in Scientific Literature. Journal of the American Society for Information Science and Technology, 57, 359-377. http://dx.doi.org/10.1002/asi.20317

Chen, C., Dubin, R., \& Kim, M. C. (2014). Emerging Trends and New Developments in Regenerative Medicine: A Scientometric Update (2000-2014). Expert Opinion on Biological Therapy, 14, 1295-1317. http://dx.doi.org/10.1517/14712598.2014.920813

Childers, D. L., Pickett, S. T., Grove, J. M., Ogden, L., \& Whitmer, A. (2014). Advancing Urban Sustainability Theory and Action: Challenges and Opportunities. Landscape and Urban Planning, 125, 320-328. http://dx.doi.org/10.1016/j.landurbplan.2014.01.022

Cruz, S. S., Costa, J. P. T., de Sousa, S. Á., \& Pinho, P. (2013). Urban Resilience and Spatial Dynamics. In Resilience Thinking in Urban Planning (pp. 53-69). Berlin: Springer. http://dx.doi.org/10.1007/978-94-007-5476-8_4

Cutter, S. L., Barnes, L., Berry, M., Burton, C., Evans, E., Tate, E. et al. (2008). A Place-Based Model for Understanding Community Resilience to Natural Disasters. Global Environmental Change, 18, 598-606. http://dx.doi.org/10.1016/j.gloenvcha.2008.07.013

Cutter, S. L., Boruff, B. J., \& Shirley, W. L. (2003). Social Vulnerability to Environmental Hazards. Social Science Quarterly, 84, 242-261. http://dx.doi.org/10.1111/1540-6237.8402002

Cutter, S. L., Burton, C. G., \& Emrich, C. T. (2010). Disaster Resilience Indicators for Benchmarking Baseline Conditions. Journal of Homeland Security and Emergency Management, 7, 1-22. http://dx.doi.org/10.2202/1547-7355.1732

Davoudi, S., Shaw, K., Haider, L. J., Quinlan, A. E., Peterson, G. D., Wilkinson, C. et al. (2012). Resilience: A Bridging Concept or a Dead End? "Reframing” Resilience: Challenges for Planning Theory and Practice Interacting Traps: Resilience Assessment of a Pasture Management System in Northern Afghanistan Urban Resilience: What Does It Mean in Planning Practice? Resilience as a Useful Concept for Climate Change Adaptation? The Politics of Resilience for Planning: A Cautionary Note: Edited by Simin Davoudi and Libby Porter. Planning Theory \& Practice, 13, 299-333. http://dx.doi.org/10.1080/14649357.2012.677124

Deppisch, S., \& Schaerffer, M. (2011). Given the Complexity of Large Cities, Can Urban Resilience Be Attained at All? In German Annual of Spatial Research and Policy 2010 (pp. 25-33). Berlin: Springer. 
http://dx.doi.org/10.1007/978-3-642-12785-4_3

Desouza, K. C., \& Flanery, T. H. (2013). Designing, Planning, and Managing Resilient Cities: A Conceptual Framework. Cities, 35, 89-99. http://dx.doi.org/10.1016/j.cities.2013.06.003

Ernstson, H., Barthel, S., Andersson, E., \& Borgström, S. T. (2010). Scale-Crossing Brokers and Network Governance of Urban Ecosystem Services: The Case of Stockholm. Ecology and society, 15, 28.

Ernstson, H., van der Leeuw, S. E., Redman, C. L., Meffert, D. J., Davis, G., Alfsen, C. et al. (2010). Urban Transitions: On Urban Resilience and Human-Dominated Ecosystems. AMBIO, 39, 531-545. http://dx.doi.org/10.1007/s13280-010-0081-9

Evans, J. P. (2011). Resilience, Ecology and Adaptation in the Experimental City. Transactions of the Institute of British Geographers, 36, 223-237. http://dx.doi.org/10.1111/j.1475-5661.2010.00420.x

Folke, C. (2006). Resilience: The Emergence of a Perspective for Social-Ecological Systems Analyses. Global Environmental Change, 16, 253-267. http://dx.doi.org/10.1016/j.gloenvcha.2006.04.002

Folke, C., Carpenter, S., Elmqvist, T., Gunderson, L., Holling, C. S., \& Walker, B. (2002). Resilience and Sustainable Development: Building Adaptive Capacity in a World of Transformations. AMBIO: A Journal of the Human Environment, 31, 437-440. http://dx.doi.org/10.1579/0044-7447-31.5.437

Folke, C., Carpenter, S. R., Walker, B., Scheffer, M., Chapin, T., \& Rockström, J. (2010). Resilience Thinking: Integrating Resilience, Adaptability and Transformability. Ecology and society, 15, 20.

Folke, C., Hahn, T., Olsson, P., \& Norberg, J. (2005). Adaptive Governance of Social-Ecological Systems. Annual Review of Environment and Resources, 30, 441-473. http://dx.doi.org/10.1146/annurev.energy.30.050504.144511

Garfield, E. (2009). From the Science of Science to Scientometrics Visualizing the History of Science with HistCite Software. Journal of Informetrics, 3, 173-179. http://dx.doi.org/10.1016/j.joi.2009.03.009

Godschalk, D. R. (2003). Urban Hazard Mitigation: Creating Resilient Cities. Natural Hazards Review, 4, 136-143. http://dx.doi.org/10.1061/(ASCE)1527-6988(2003)4:3(136)

Grimm, N. B., Faeth, S. H., Golubiewski, N. E., Redman, C. L., Wu, J., Bai, X. et al. (2008). Global Change and the Ecology of Cities. Science, 319, 756-760. http://dx.doi.org/10.1126/science.1150195

Grimm, N. B., Grove, J. G., Pickett, S. T., \& Redman, C. L. (2000). Integrated Approaches to Long-Term Studies of Urban Ecological Systems Urban Ecological Systems Present Multiple Challenges to Ecologists-Pervasive Human Impact and Extreme Heterogeneity of Cities, and the Need to Integrate Social and Ecological Approaches, Concepts, and Theory. BioScience, 50, 571-584. http://dx.doi.org/10.1641/0006-3568(2000)050[0571:IATLTO]2.0.CO;2

Gunderson, L. H., \& Holling, C. S. (2002). Panarchy: Understanding Transformations in Systems of Humans and Nature. Washington DC: Island Press.

Holling, C. S. (1973). Resilience and Stability of Ecological Systems. Annual Review of Ecology and Systematics, 4, 1-23. http://dx.doi.org/10.1146/annurev.es.04.110173.000245

Jha, A. K., Miner, T. W., \& Stanton-Geddes, Z. (2013). Building Urban Resilience: Principles, Tools, and Practice. World Bank Publications. http://dx.doi.org/10.1596/978-0-8213-8865-5

Kim, M. C., \& Chen, C. M. (2015). A Scientometric Review of Emerging Trends and New Developments in Recommendation Systems. Scientometrics, 104, 239-263. http://dx.doi.org/10.1007/s11192-015-1595-5

Lang, T. (2011). Urban Resilience and New Institutional Theory-A Happy Couple for Urban and Regional Studies? In B. Müller (Ed.), German Annual of Spatial Research and Policy 2010 (pp. 15-24). Berlin: Springer. http://dx.doi.org/10.1007/978-3-642-12785-4 2

Leichenko, R. (2011). Climate Change and Urban Resilience. Current Opinion in Environmental Sustainability, 3, $164-168$. http://dx.doi.org/10.1016/j.cosust.2010.12.014

Lu, P. (2014). Spatial Planning and Urban Resilience in the Context of Flood Risk: A Comparative Study of Kaohsiung, Tainan and Rotterdam. Delft: Delft University of Technology.

Luthar, S. S., Cicchetti, D., \& Becker, B. (2000). The Construct of Resilience: A Critical Evaluation and Guidelines for Future Work. Child Development, 71, 543-562. http://dx.doi.org/10.1111/1467-8624.00164

Masten, A. S. (2001). Ordinary Magic: Resilience Processes in Development. American Psychologist, 56, 227-238. http://dx.doi.org/10.1037/0003-066X.56.3.227

Masten, A. S., Best, K. M., \& Garmezy, N. (1990). Resilience and Development: Contributions from the Study of Children Who Overcome Adversity. Development and Psychopathology, 2, 425-444.

http://dx.doi.org/10.1017/S0954579400005812

Masten, A. S., \& Coatsworth, J. D. (1998). The Development of Competence in Favorable and Unfavorable Environments: Lessons from Research on Successful Children. American Psychologist, 53, 205-220.

http://dx.doi.org/10.1037/0003-066X.53.2.205 
Meerow, S., \& Newell, J. P. (2015). Resilience and Complexity: A Bibliometric Review and Prospects for Industrial Ecology. Journal of Industrial Ecology, 19, 236-251. http://dx.doi.org/10.1111/jiec.12252

Müller, B. (2011). Urban and Regional Resilience-A New Catchword or a Consistent Concept for Research and Practice? In B. Müller (Ed.), German Annual of Spatial Research and Policy 2010 (pp. 1-13). Berlin: Springer. http://dx.doi.org/10.1007/978-3-642-12785-4_1

Newman, P., Beatley, T., \& Boyer, H. (2009). Resilient Cities: Responding to Peak Oil and Climate Change. Washington DC: Island Press.

Norris, F. H., Stevens, S. P., Pfefferbaum, B., Wyche, K. F., \& Pfefferbaum, R. L. (2008). Community Resilience as a Metaphor, Theory, Set of Capacities, and Strategy for Disaster Readiness. American Journal of Community Psychology, 41, 127-150. http://dx.doi.org/10.1007/s10464-007-9156-6

Ouyang, M., \& Wang, Z. (2015). Resilience Assessment of Interdependent Infrastructure Systems: With a Focus on Joint Restoration Modeling and Analysis. Reliability Engineering \& System Safety, 141, 74-82. http://dx.doi.org/10.1016/j.ress.2015.03.011

Pelling, M. (2003). The Vulnerability of Cities. Earthscan, London.

Pickett, S. T., Cadenasso, M. L., \& Grove, J. M. (2004). Resilient Cities: Meaning, Models, and Metaphor for Integrating the Ecological, Socio-Economic, and Planning Realms. Landscape and Urban Planning, 69, 369-384. http://dx.doi.org/10.1016/j.landurbplan.2003.10.035

Rutter, M. (1987). Psychosocial Resilience and Protective Mechanisms. American Journal of Orthopsychiatry, 57, $316-331$. http://dx.doi.org/10.1111/j.1939-0025.1987.tb03541.x

Sellberg, M. M., Wilkinson, C., \& Peterson, G. D. (2015). Resilience Assessment: A Useful Approach to Navigate Urban Sustainability Challenges. Ecology and Society, 20, 43. http://dx.doi.org/10.5751/ES-07258-200143

Smit, B., \& Wandel, J. (2006). Adaptation, Adaptive Capacity and Vulnerability. Global Environmental Change, 16, 282292. http://dx.doi.org/10.1016/j.gloenvcha.2006.03.008

Surjan, A., Sharma, A., \& Shaw, R. (2011). Chapter 2: Understanding Urban Resilience. Climate and Disaster Resilience in Cities (Community, Environment and Disaster Risk Management, Vol. 6, pp. 17-45). Emerald Group Publishing Limited.

Tate, E. (2012). Social Vulnerability Indices: A Comparative Assessment Using Uncertainty and Sensitivity Analysis. Natural Hazards, 63, 325-347. http://dx.doi.org/10.1007/s11069-012-0152-2

Tyler, S., \& Moench, M. (2012). A Framework for Urban Climate Resilience. Climate and Development, 4, 311-326. http://dx.doi.org/10.1080/17565529.2012.745389

Vale, L. J. (2014). The Politics of Resilient Cities: Whose Resilience and Whose City? Building Research \& Information, 42, 191-201. http://dx.doi.org/10.1080/09613218.2014.850602

Walker, B., Holling, C. S., Carpenter, S. R., \& Kinzig, A. (2004). Resilience, Adaptability and Transformability in Social-Ecological Systems. Ecology and society, 9, 5.

Walker, B. H., Anderies, J. M., Kinzig, A. P., \& Ryan, P. (2006). Exploring Resilience in Social-Ecological Systems through Comparative Studies and Theory Development: Introduction to the Special Issue. Ecology and Society, 11, 12.

Wang, J., \& Liu, Z. (2014). A Bibliometric Analysis on Rural Studies in Human Geography and Related Disciplines. Scientometrics, 101, 39-59. http://dx.doi.org/10.1007/s11192-014-1388-2

Werner, E. E. (1989). High-Risk Children in Young Adulthood: A Longitudinal Study from Birth to 32 Years. American Journal of Orthopsychiatry, 59, 72-81. http://dx.doi.org/10.1111/j.1939-0025.1989.tb01636.x

Werner, E. E., \& Smit, R. (1982). Vulnerable but Invincible: Kauai’s Children Come of Age. New York: McGraw-Hill.

Werner, E. E., \& Smith, R. S. (1992). Overcoming the Odds: High Risk Children from Birth to Adulthood. Ithaca, NY: Cornell University Press.

Wilbanks, T., Fernandez, S., Backus, G., Garcia, P., Jonietz, K., Kirshen, P. et al. (2012). Climate Change and Infrastructure, Urban Systems. Berlin: Springer.

Wilkinson, C. (2012). Social-Ecological Resilience: Insights and Issues for Planning Theory. Planning Theory, 11, $148-169$. http://dx.doi.org/10.1177/1473095211426274

Wisner, B., Blaikie, P., Cannon, T., \& Davis, I. (2004) At Risk: Natural Hazards, People’s Vulnerability and Disasters. Routledge.

Wyman, P. A., Cowen, E. L., Work, W. C., \& Parker, G. R. (1991). Developmental and Family Milieu Correlates of Resilience in Urban Children Who Have Experienced Major Life Stress. American Journal of Community Psychology, 19, 405-426.

Wyman, P. A., Cowen, E. L., Work, W. C., Raoof, A., Gribble, P. A., Parker, G. R. et al. (1992). Interviews with Children Who Experienced Major Life Stress: Family and Child Attributes That Predict Resilient Outcomes. Journal of the Ameri- 
can Academy of Child \& Adolescent Psychiatry, 31, 904-910.

http://dx.doi.org/10.1097/00004583-199209000-00019

Xu, L., Marinova, D., \& Guo, X. (2015). Resilience Thinking: A Renewed System Approach for Sustainability Science. Sustainability Science, 10, 123-138. http://dx.doi.org/10.1007/s11625-014-0274-4 